\title{
MECHANIZED HARVESTING TESTS PERFORMED BY GRAPE HARVESTERS IN SUPER INTENSIVE OLIVE ORCHARD CULTIVATION IN SPAIN
}

\author{
Gennaro Giametta, Bruno Bernardi
}

\section{Introduction}

The rapid and sweeping changes occurred in the last few years in the world have been crucial driving forces behind the evolution of olive growing practices on a global scale. These drives to change, which occurred within a framework of unchanged, if not decreasing, Community funds, are gradually modifying the traditional olive growing scenarios thanks to the successful advent of a modern mechanized and specialized olive orchard cultivation where resource efficiency improvements and production cost reduction have become mandatory [Giametta 2006a; Scaramuzzi 2006c].

In particular, the olive growing innovation process is based on a model referred to as "super intensive", which is characterized by an elevated planting density (up to and over 2,000 plants/ha) whose main advantage lies in highly-efficient mechanized harvesting operations performed uninterruptedly by means of the same grape harvesters long used to collect grapes and now equipped with special operating devices meant to adapt them to olive grove harvest [Cini 2007; Rallo 2006].

Such super intensive model, which was brought in the early 90s in Cataluña, has by now spread to other regions of Spain (Aragona, Andalucía, etc.) as well as to other olive growing countries, including Tunisia, Morocco, the USA (California), Australia, Portugal, France, Chile, Argentina [Arrivo 2006; Giametta 2006a; Loreti 2007], while in Italy the first super intensive olive groves were planted just a few years ago.

The form of training generally thought to fit better than the others to this new olive growing model is made of plants with a central axis slightly taller than 2 $\mathrm{m}$, which can however reach up to $4 \mathrm{~m}$ of height, with the final $1.5 \mathrm{~m}$ portion flexible enough to avoid damage by the harvester.

\section{Paper received 04.04.2008; accepted 20.01.2009}

Prof. Gennaro Giametta, full professor; Dr. Bruno BERNARDI, PhD; Department STAFA, University Mediterranea of Reggio Calabria - Italy. E-mail: gennaro.giametta@ unirc.it

The authors have contributed equally to the present work.
The length of the lateral branches, which usually depart from the central axis at a height of $0.50-0.70 \mathrm{~m}$ from the ground and are oriented in parallel with the row, gradually decreases from the basis to the top of the crown [Iannotta 2006; Rallo 2006]. Such form of monocone training must be then modified over time through appropriate pruning operations meant to reduce the size of tree crown and obtain flat surfaces responding better to the requirements of grape harvesters [Fontanazza 1998b; Iannotta 2006; Rallo 2006].

Planting distance mainly depends on factors including soil fertility, cultivar vigor and olive grove cropping system (irrigated, non irrigated, etc.). This system normally uses a spacing of about $1.35-1.50 \mathrm{~m}$ between trees and about 3-4 m between rows. Within three years of planting, tree crowns literally close the spaces between trees forming a sort of uninterrupted hedge-like row.

If appropriately fertilized and irrigated, plants start bearing fruit within two years, maximum three years of planting [Bellomo 2007; Rallo 2006].

This system is based on the assumption that only an integral mechanization of the harvesting operations is likely to guarantee olive growing maximum economic efficiency provided that this mechanization be combined with appropriate plant growth and production. As a matter of fact, unlike traditional olive growing that, requiring a lot of the ever more expensive and unavailable farm labor, is turning out to be economically unsustainable in the absence of EU production subsidies, the system in question allows to respond to the needs of economic sustainability of the olive growing sector. The grape harvesters worksite is, in fact, made of just two workers, one driving the harvester and the other in charge of the trailer destined to collect and handle harvested olives. This allows for a remarkable reduction of the harvesting costs, while avoiding any damages to both drupes and trees, and a rapid harvest, a key element in the process of production of a top-quality olive oil with a very low acidity [Giametta 2006a].

By contrast, in addition to the high planting costs, such super intensive model calls for large, mostly level groves. The main drawback of this kind of the sys- 
tem in question is represented by the difficulty to keep tree vigor under control to allow harvesters to pass in the rows.

As there exists no "plant material" specifically adapted to this kind of olive groves, most of these latter are made of the varieties "Arbequina", "Arbosana" (Spanish) and "Koroneiki" (Greek) [Godini 2006; Rallo 2006].

The adoption of this model of cultivation, which could be conceived as a short-term investment (assuming a life span of 15-20 years for this kind of plantings), is however resulting in a "global revolution in olive tree cultivation techniques" [Loreti 2007; Scaramuzzi 1962a; Scaramuzzi 1964b], as some traditional elements of olive growing, including planting density, training method and drupes collection need sweeping innovative fixes.

The present study is intended to explore both productivity and work capacity of two of the most commonly used grape harvesters, Grégoire G120SW and New Holland Braud VX680, in a view to assessing their harvesting performance by a series of tests conducted in Andalucía and in Cataluña.

\section{Materials and methods}

\subsection{Infield Surveys}

In Andalucía tests were conducted at experimental olive groves where comparative analyses were jointly carried out in terms of varieties (Thesis $A$ ) and density (Thesis $B$ ), by the University of Cordoba, IFAPA (Instituto Andaluz De Investigación y Formación Agraría, Pesquera y Alimentaria) and the company Todolivo [De la Rosa 2006a; De la Rosa 2006b].

Both olive groves with seven-year-old plants, have a North-South orientation (which provides for an excellent natural illumination) and drip fertirrigation

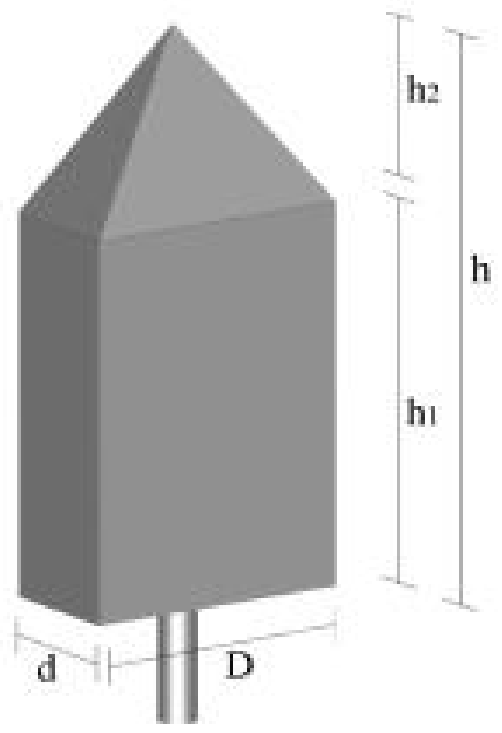

Fig. 1 - Scheme of the crown adopted to calculate the volume.

systems (DFS). The dose of irrigation ranges between 2,000 and $2,300 \mathrm{~m}^{3} /$ ha per year.

Plants have one only axis and are $4 \mathrm{~m}$ tall, the last $1.5 \mathrm{~m}$ being flexible. Crown branching starts at around $0.70 \mathrm{~m}$ above the ground.

Thanks to the specific management techniques used to obtain a crown fit for mechanized harvesting operations, foliage shape has been assumed to be similar to the solid shown in Fig. 1, utilizing the following formula to calculate crown volumes $\left(V_{c}\right)$ :

$$
V_{c}=h_{1}(D \cdot d)+1 / 3(D \cdot d) \cdot h_{2}
$$

where:

$h_{l}=2 / 3$ of total height of the crown (h) [m];

$h_{2}=1 / 3$ of total height of the crown (h) [m];

$D=$ longer diameter (between trees) $\quad[\mathrm{m}]$;

$d=$ shorter diameter (between rows) $\quad[\mathrm{m}]$.

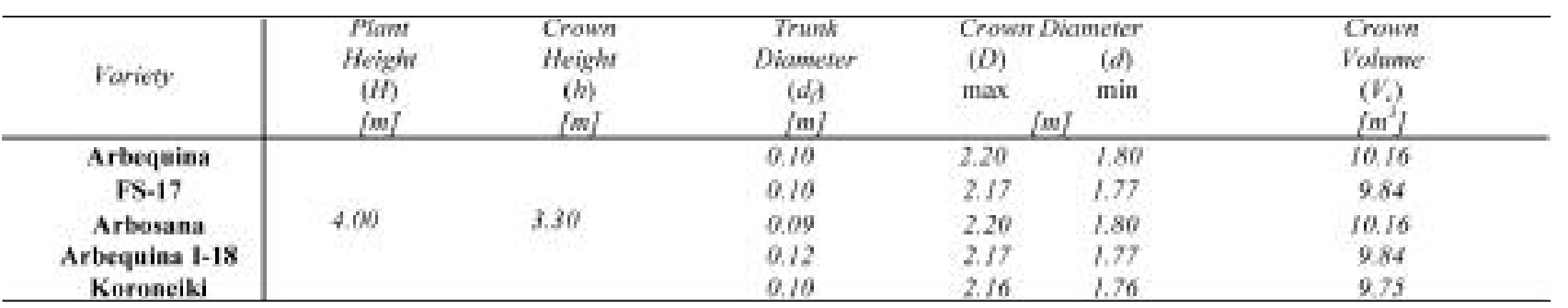

TABLE 1 - Comparison of the average sizes of the five varieties studied.

\begin{tabular}{|c|c|c|c|}
\hline Variery & $\begin{array}{c}\text { Testod Ronst } \\
\text { [n] }\end{array}$ & $\begin{array}{l}\text { Fow fwerage Levegds } \\
\qquad\{\mathrm{m}\}\end{array}$ & $\begin{array}{c}\text { Plinity per Row } \\
\qquad \mathrm{H}\}\end{array}$ \\
\hline Arbequina & 3 & 50 & 37 \\
\hline FS:17 & 3 & 32 & 24 \\
\hline Arbosana & 3 & 49 & 36 \\
\hline Arhequina 1-18 & 3 & 46 & 34 \\
\hline Keronciki & 3 & 34 & 23 \\
\hline
\end{tabular}



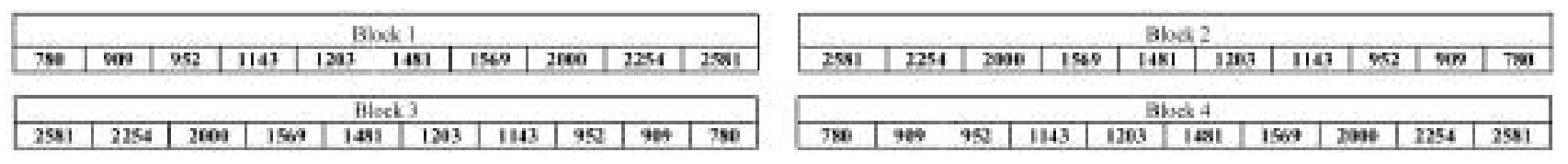

TABLE 3 - Distribution of the different planting distances studied.

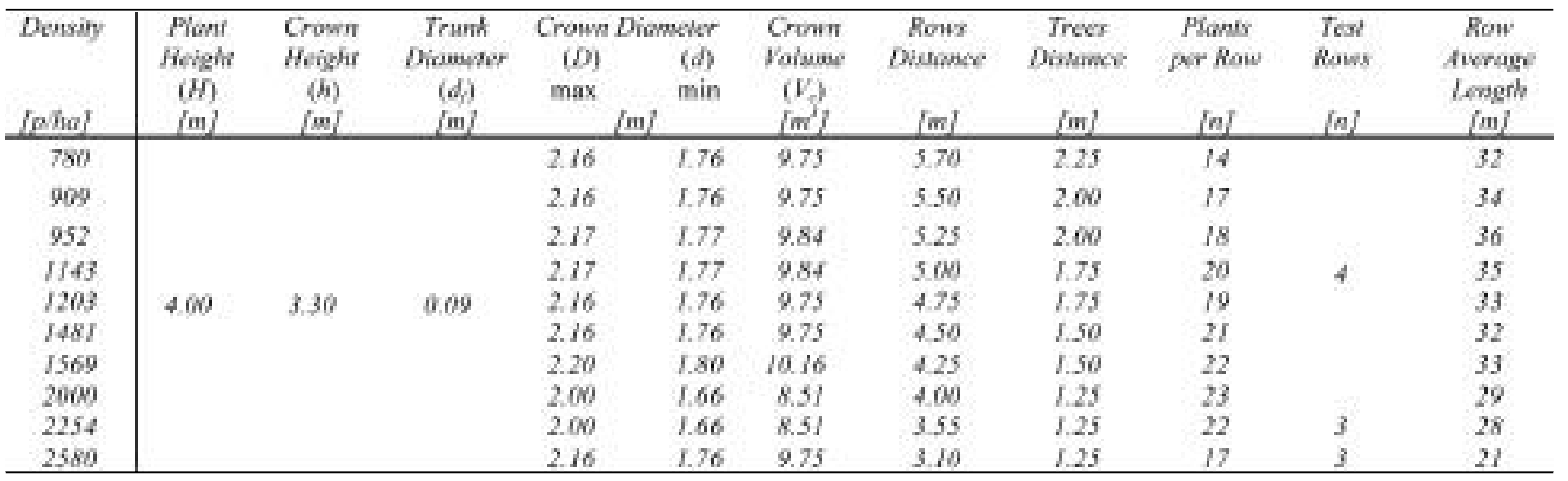

TABLE 4 - Features of the plants (cv.“Arbequina” Agromillora selection) and planting distances.

Thesis $A$ was focused on a comparative analysis between the following varieties: "Arbequina" (Agromillora selection), "Arbequina IRTA-I 18”, "Arbosana", "Koroneiki" and "Fs-17" (Table 1) [Barranco 2004; Fontanazza 1996a]. All these varieties had the same planting distance of $3.75 \mathrm{~m} \mathrm{x} 1.35 \mathrm{~m}$ (1975 plants/ha) and were distributed according to a randomized block design with four repeats. Table 2 shows the main technical features of the areas tested which concerned blocks 2, 3 and 4 .

Thesis $B$ focuses on the comparison of 10 different planting densities (from 780 to 2,581 plants/ha with a spacing from $3.1 \mathrm{~m}$ to $5.7 \mathrm{~m}$ between rows and from $1.25 \mathrm{~m}$ to $2.25 \mathrm{~m}$ between trees) in "Arbequina" variety (Agromillora selection) olive groves. Both the sizes and the technical features of the planting densi-

\begin{tabular}{|c|c|c|c|}
\hline Elenctits & & $\begin{array}{c}\text { Unit of } \\
\text { measurement }\end{array}$ & Value \\
\hline Plan beigho & (H) & [m] & 2.40 \\
\hline Crown heigh & (h) & [m] & 1.70 \\
\hline Trunk diamefer & $\left(d_{i}\right)$ & {$[m]$} & 0.12 \\
\hline Crown langer dilaweter & (D) & {$[m]$} & 1.56 \\
\hline Cromen shorter diamefer & (d) & [m] & 1.04 \\
\hline Orown volume & $\left(V_{*}\right)$ & {$\left[n^{3}\right]$} & 2.10 \\
\hline
\end{tabular}

TABLE 5 - Average values for individual plants..

\begin{tabular}{l|c|c}
\hline \multicolumn{1}{c|}{ Elements } & $\begin{array}{c}\text { Unit of } \\
\text { messurement }\end{array}$ & Value \\
\hline Tex mows & {$[\mathrm{n}]$} & 5 \\
Row aneruge fength & {$[\mathrm{m}]$} & 284 \\
Plans per now & {$[\mathrm{n}]$} & 389 \\
\hline
\end{tabular}

TABLE 6 - Technical features of the surfaces tested. ties under study, arranged in ascending and descending order (Table 3), are reported in Table 4.

In Cataluña tests were instead conducted in a fiveyear old olive grove located in Reus (Tarragona), which had been planted with "Arbequina" variety ("Agromillora" selection) olive trees [Tous 2006]. The olive grove in question has a $1.50 \mathrm{~m} \times 3 \mathrm{~m}$ planting distance, a plant density of about 2,500 plants/ha, a North East-South West orientation and a drip fertirrigation (DFS) system. The annual dose of irrigation is about $1,500 \mathrm{~m}^{3} / \mathrm{ha}$.

Tables 5 and 6 give the parameters of the plants present on the surface tested.

\subsection{Grape Harvesters and Worksites Used}

The harvesters utilized during the tests, are the Grégoire G120 SW in Andalucía (fig. 2) and the New Holland Braud VX 680 in Cataluña (fig. 3).

These new machines make use of the technology used to harvest grapes from widely spaced rows of vines with some essential modifications that turn them in olive harvesters: an increased number of shakers for them to be adapted at best to the productive area of the hedge-like rows of the olive groves in question, the addition of a conveyor immediately before the picking tunnel to help row introduction into the tunnel itself. The width of this latter can also be adjusted to the width of the "hedge" which is expected to increase in time [Arrivo 2006].

Both row harvesters are essentially made of a fourwheel drive frame equipped with an integrated hydrostatic transmission system which allows to detect the ideal advancement velocity, save it in memory and use it again when resetting harvesting operations for the next row. The harvesting unit is hinged to the carrying frame for it to be pivoting and self-aligning, i.e. having a complete freedom of movements, the har- 
vesting head turns out to be suspended over the machine carrying frame.

In addition it is possible to make an electrohydraulic check of the four-wheel drive thus guaranteeing a $90^{\circ}$ turning radius which allows wheels to make $\mathrm{U}$ turns while the rear wheel is connected to the frame of the vehicle by a supporting base enabling the same to be steered freely while having a ground-touching point. Moreover a hydraulic compensation and elevation system allows for transverse leveling on slopes up to $30 \%$.

The harvesters move while the hedge-like row is processed in the harvesting tunnel and the drupes are collected uninterruptedly thanks to a system of conveyor belts (located in the lower part of the harvester itself) sticking to the trunks [Arrivo 2006; Giametta 2006a]. These conveyors, made of highly elastic and deformable material, have a flake-shaped structure in the Grégoire Harvester and a basket-shaped structure in the New Holland Braud Harvester. In the first case (Grégoire) the "flakes" run over the trunks and open whenever they run into one of them (trunks): this is likely to result in certain level of damage and loss of the drupes harvested. The basket-shaped system (Braud patent) instead reduces at most harvested olives handling as it virtually winds around the trunk, i.e. the basket-shaped conveyor proceeds at the same advancement velocity of the harvester, but in the opposite direction thus always being motionless until unloading takes place [Corradi 2005].

The drupes detachment apparatus is made of arms located on the inner side of the harvester which are equipped with vibrating rods designed to comb and shake the external part of the foliage. Oscillation rate can range between 450 and 480 beats per minute [Barranco 2004]. The Grégoire shake system, made of 28 molded bow beaters, is a brakerods shake system (A.R.C.) with the two ends of the beaters hinged thus impacting vegetation only with the central part of bending. The New Holland Braud harvesting unit, which is characterized by a controlled dynamics system (C.D.S) of harvesting, is conceptually similar to that of Grégoire, but it is made of 24 teflon bow rods that enable to process individual plants with an intensity that varies according with the area of contact with the harvesting head by means of a much more controlled and progressive shaking mechanism [Arrivo 2006].

Both machines are in addition equipped with four suckers (two on the back of the machine and two at the end of the conveyor) which are meant to remove leaves from the olives harvested. The reversing dump bins have a load capacity up to $3,200 \mathrm{~kg}$ [Giametta 2006a].

The worksite is made of two workers, one driving the grape harvester and the other in charge of the trailer from the rows to the oil mill; in Andalucía the loading area was located at a certain distance from the area where the tests were performed to allow for weighing operations of the product harvested.

The assessment of the time taken by the different

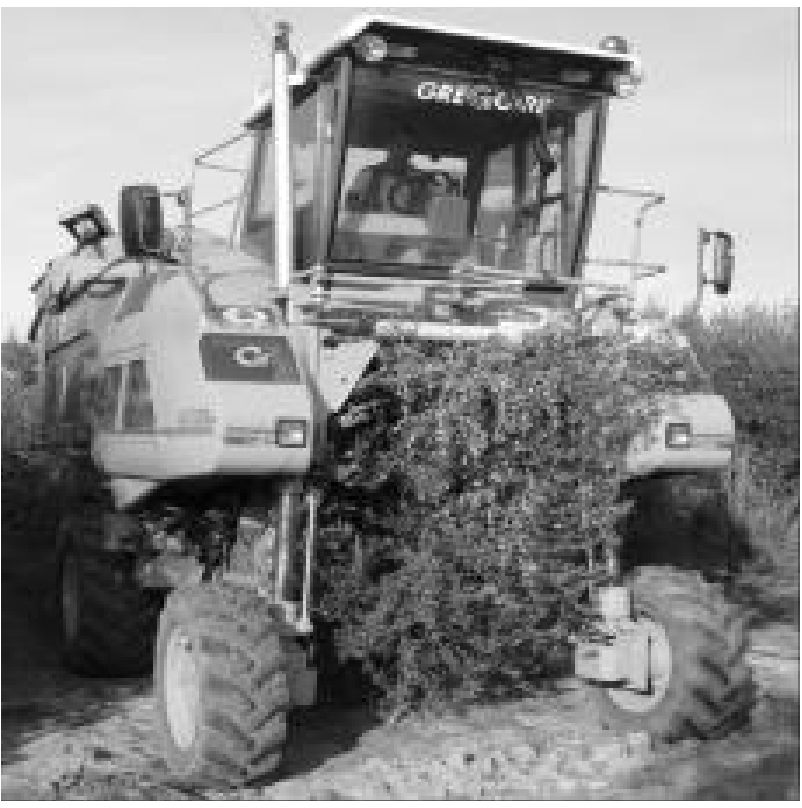

Fig. 2 - Grégoire G 120 SW at work.

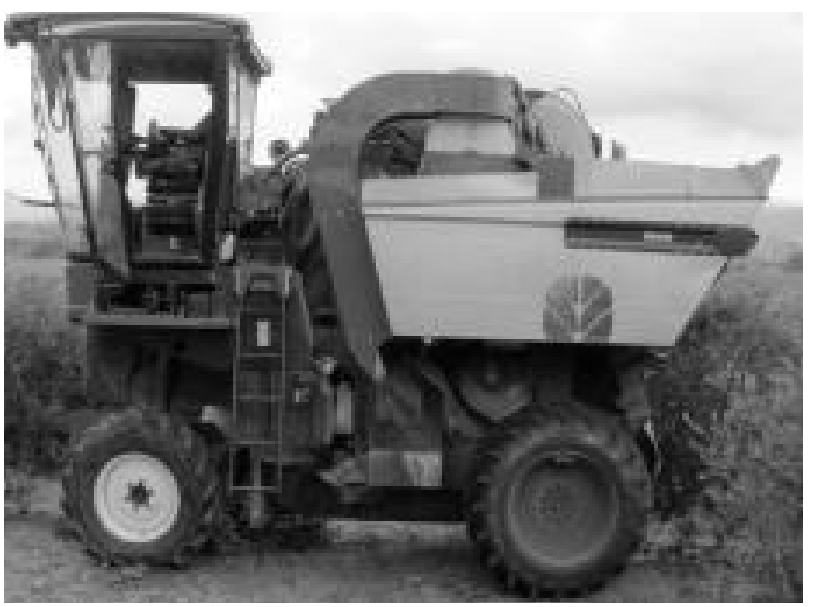

Fig. 3 - New Holland Braud VX 680.

operations envisaged by the tests under consideration has been made under C.I.O.S.T.A. ranking requirements [Bolli 1987], i.e. tests were considered to start when the harvester was positioned opposite to the row to begin harvesting operations, and to end when the product was fully unloaded.

\section{Results}

\subsection{Andalucía}

Tables 7 and 8 give distribution data in terms of actual working hours per surface units (TE), idle time (TM), and accessory time (TA) as assessed on the basis of the surveys carried out during the tests. Relying on the above distribution data it has also been possible to assess the time taken by the different operations in the two theses under study.

Figure 4 (Thesis $A$ ) indicates that the lowest harvester operation time (TO) $(4.1 \mathrm{~h} / \mathrm{ha})$ has been regis- 


\begin{tabular}{|c|c|c|c|c|c|c|c|}
\hline \multirow[t]{2}{*}{ Variety } & \multirow{2}{*}{$\begin{array}{l}\text { TE } \\
\text { h/ha }\end{array}$} & \multicolumn{4}{|c|}{ TA } & \multirow{2}{*}{$\begin{array}{l}\text { To } \\
\text { tha }\end{array}$} & \multirow{2}{*}{$\begin{array}{l}\text { TM } \\
\text { hha } \\
\end{array}$} \\
\hline & & & $\%$ & & hha & & \\
\hline Arbequins & 3.5 & 34 & 66 & $=$ & 5.7 & 5.2 & a.t \\
\hline $\mathrm{FS}-17$ & 5.8 & 22 & 78 & - & 2.5 & 8,5 & 1.2 \\
\hline Arbassna & 3.7 & 25 & 75 & . & 1.5 & 4.6 & 0.2 \\
\hline $1-18$ & 3.0 & 25 & 79 & - & I.I & 4.) & 0.2 \\
\hline Koronciki & 4.7 & 35 & 85 & . & 0.7 & 6.4 & 1.3 \\
\hline
\end{tabular}

Note: $\mathrm{TE}=$ actual working time, $\mathrm{TA}=$ accessory time, $\mathrm{TAV}$ $=$ time to turn, $\mathrm{TAS}=$ unloading time, $\mathrm{TAC}=$ servicing time, $\mathrm{TO}=$ operational time, $\mathrm{TM}=$ idle time.

TABLE $\quad 7$ - Average times assessed for Thesis A.

\begin{tabular}{|c|c|c|c|c|c|c|c|}
\hline \multirow{3}{*}{ Density } & \multirow[t]{2}{*}{$\mathrm{TE}$} & \multicolumn{4}{|c|}{ TA } & \multirow[t]{2}{*}{ TO } & \multirow[t]{2}{*}{$T M$} \\
\hline & & TAV & TAS & $\mathrm{TAC}$ & TOTAL & & \\
\hline & hula & & $\%$ & & hha & Wha & Wha \\
\hline 780 & 1.9 & 47 & 53 & - & 0.7 & 2.6 & 05 \\
\hline 900 & 1.7 & 40 & 60 & . & 0.9 & 2.8 & $\because$ \\
\hline 952 & 1.9 & 34 & 06 & - & as & 2.7 & - \\
\hline 1143 & 2.3 & $4 f$ & 59 & - & 1.0 & 3.) & - \\
\hline 1203 & 2.2 & 34 & 66 & - & 1.0 & 3.2 & 03 \\
\hline 1431 & 27 & $4 f$ & 59 & - & I. 1 & 3.8 & 03 \\
\hline 1569 & 2.8 & 39 & 61 & . & 10 & 3.8 & 3.0 \\
\hline 2000 & 3.7 & 34 & 66 & . & I.S & 4.6 & 0.7 \\
\hline 2254 & 3.4 & 26 & 67 & 7 & 2.2 & 5.6 & 1.7 \\
\hline 2580 & 3.8 & 38 & 62 & - & 2.2 & 6.0 & 13 \\
\hline
\end{tabular}

TABLE 8 - Average times assessed for Thesis B.

tered for the "Arbequina I-18" variety. The "Arbosana" and "Arbequina (Agromillora selection)" varieties follow with slightly higher values; Figure 5 (Thesis B) highlights instead that harvester operation time $(2.6 \mathrm{~h} / \mathrm{ha})$ has been registered for densities of 780 plants/ha and 909 plants/ha.

On the basis of the above data it has been possible to infer work capacity, productivity and efficiency for both Theses as reported in Tables 9 and 10 .

As far as Thesis $A$ is concerned, the average speed of advancement of the machine along the rows turned out to be $0.74 \mathrm{~km} / \mathrm{h}$ for an actual work capacity $(\mathrm{CE})$ of $0.26 \mathrm{ha} / \mathrm{h}$. The total of accessory times (TA) was instead equal to $1.64 \mathrm{~h} / \mathrm{ha}$; the average time taken to

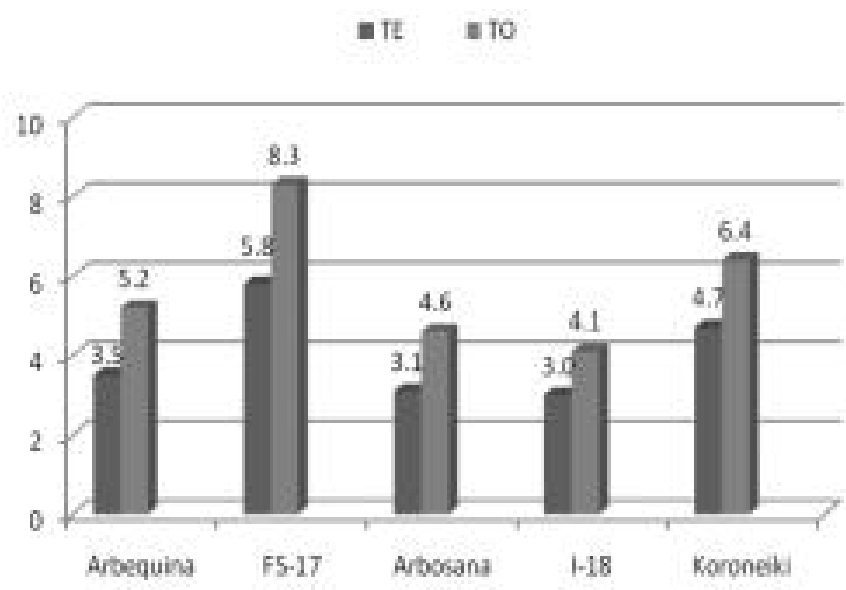

Fig. 4 - Comparison of the harvester operation times per variety (Thesis A). turn the machine (TAV) accounted for $25 \%$ of the total of accessory times while the remaining $75 \%$ of TA was accounted for by unloading times (TAS). The total of the harvester operation time of the machine (TO) was $5.6 \mathrm{~h} / \mathrm{ha}$ whereas the work capacity of the machine $(\mathrm{CO})$ turned out to be $0.18 \mathrm{ha} / \mathrm{h}$.

As far as Thesis $B$ is concerned, the average speed of advancement was $0.93 \mathrm{~km} / \mathrm{h}$ whereas the actual work capacity (CE) was $0.41 \mathrm{ha} / \mathrm{h}$. The total of accessory times (TA) was $0.57 \mathrm{~h} / \mathrm{ha}$, with a $37 \%$ and a $62 \%$ incidence for turns and unloading, respectively. The average operation time of the machine (TO) was 3.8 $\mathrm{h} / \mathrm{ha}$, whereas the work capacity of the machine (CO) turned out to be $0.29 \mathrm{ha} / \mathrm{h}$.

Iddle time turns out to be neglectable compared to the hours of operation the grape harvesters used in both Theses. The results obtained in terms of harvest efficiency indicate yields of $13.4 \mathrm{t} / \mathrm{ha}$ with a work productivity (PO) of 0.09 ha/hop for Thesis A, whereas in Thesis $B$ the same parameters were $8.6 \mathrm{t} / \mathrm{ha}$ in terms of harvest yield and $0.14 \mathrm{ha} / \mathrm{hop}$ in terms of work productivity.

Production losses, i.e. the amounts of drupes remained on the branches and therefore not processed by the harvester, were on the order of $8 \%$.

\subsection{Cataluña}

The results of the tests performed (Table 11) have allowed to assess a time of operation (TO) per unit of surface of $2.3 \mathrm{~h} / \mathrm{ha}$ with a total accessory time (TA) of $0.2 \mathrm{~h} / \mathrm{ha}$. The time taken to turn the machine (TAV) accounted for $35 \%$ of total accessory times, whereas $65 \%$ of these latter were accounted for by unloading times (TAS). The actual hours of operation of the harvester (TE) were $2.1 \mathrm{~h} / \mathrm{ha}$, while idle time amounted to $0.1 \mathrm{~h} /$ ha (Figure 6 ).

Table 12 reports the speed of advancement of the harvester along the rows which was $1.6 \mathrm{~km} / \mathrm{h}$ for an actual work capacity (CE) of the same machine of $0.48 \mathrm{ha} / \mathrm{h}$. In terms of harvest efficiency, the yield obtained was $8.4 \mathrm{t} / \mathrm{ha}$.

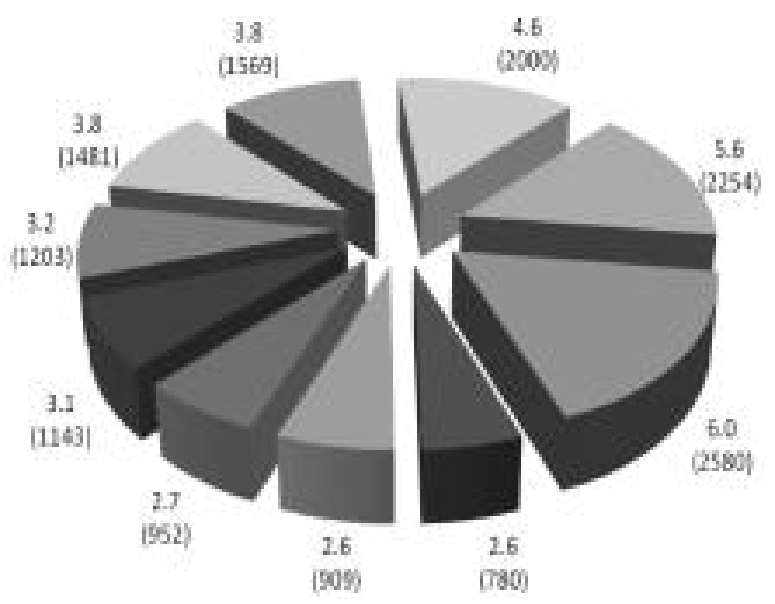

Fig. 5 - Comparison of operational working times per planting density (Thesis B); densities per hectare are given in brackets. 


\begin{tabular}{|c|c|c|c|c|c|c|c|c|c|}
\hline \multirow[t]{3}{*}{ Variety } & \multirow{3}{*}{$\begin{array}{c}\text { Tafd Work } \\
\text { Lengrh } \\
\text { fiil }\end{array}$} & \multirow{3}{*}{$\begin{array}{c}\text { Prodinct } \\
\text { Havesied } \\
\text { [r] }\end{array}$} & \multirow{3}{*}{$\begin{array}{c}\text { Horresting } \\
\text { cfirciency } \\
\{\text { Y }]\end{array}$} & \multirow{3}{*}{$\begin{array}{l}\text { Yield } \\
\langle w h i\}\end{array}$} & \multirow{3}{*}{ 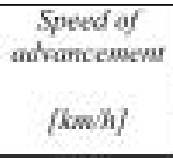 } & \multicolumn{2}{|c|}{$\begin{array}{c}\text { Work } \\
\text { Capacity }\end{array}$} & \multirow{2}{*}{\multicolumn{2}{|c|}{$\begin{array}{c}\text { Work } \\
\text { Productivity } \\
\text { In Terms of TO }\end{array}$}} \\
\hline & & & & & & In Terms of TE & In Terms of To & & \\
\hline & & & & & & {$[$ hash][h/ha][th] } & [ha'h][hha][th] & [hathoy & [thop] \\
\hline Arbequina & 150 & 0.52 & 95 & 9.5 & 0.8 & $\begin{array}{llll}0.28 & 3.50 & 2.60\end{array}$ & $\begin{array}{lll}0.19 & 5.2 & 1.76\end{array}$ & 0.10 & 0.88 \\
\hline FS-17 & 97 & 0.53 & 88 & 11,0 & a.s & $\begin{array}{llll}0.87 & 5.80 & 2.00\end{array}$ & $0.12 \quad 83 \quad 1.40$ & 0.06 & 0.70 \\
\hline Arbosana & 147 & 0.99 & 94 & 18.0 & 0.9 & $\begin{array}{llll}0.32 & 3.10 & 5.73\end{array}$ & $\begin{array}{llll}0.22 & 4.6 & 3.89\end{array}$ & $0.1 /$ & 1.95 \\
\hline $1-18$ & 138 & 0.43 & 95 & 8.3 & 0.9 & $\begin{array}{llll}0.33 & 3.00 & 2.79\end{array}$ & $0.25 \quad 4.5 \quad 2.03$ & 0.82 & 1.02 \\
\hline Koroneiki & 102 & 0.74 & $9 f$ & 19.4 & 0.6 & $0.21 \quad 4.70 \quad 4.10$ & $0.35 \quad 6.4 \quad 3.00$ & 0.08 & 1.50 \\
\hline
\end{tabular}

TABLE 9 - Average values of the parameters assessed and harvesting capacities - Thesis A.

\begin{tabular}{|c|c|c|c|c|c|c|c|c|c|c|c|}
\hline \multirow{3}{*}{ Density } & \multirow{3}{*}{$\begin{array}{c}\text { Toval Work } \\
\text { length } \\
{[w]}\end{array}$} & \multirow{3}{*}{$\begin{array}{c}\text { Prondwer } \\
\text { Hornested } \\
\text { [r] }\end{array}$} & \multirow{3}{*}{$\begin{array}{l}\text { Harvesing } \\
\text { efficiency } \\
\text { [\%] }\end{array}$} & \multirow{3}{*}{$\begin{array}{l}\text { Yheid } \\
\text { [oher }\end{array}$} & \multirow{3}{*}{$\begin{array}{c}\text { Spoctid of } \\
\text { odivascement } \\
{[\mathrm{km} / \mathrm{h}]}\end{array}$} & \multicolumn{4}{|c|}{$\begin{array}{c}\text { Work } \\
\text { Capacity } \\
\end{array}$} & \multirow{2}{*}{\multicolumn{2}{|c|}{$\begin{array}{c}\text { Work } \\
\text { Productivily } \\
\text { In Tems of TC }\end{array}$}} \\
\hline & & & & & & \multicolumn{3}{|c|}{ In Terms of TE } & In Terms of TO & & \\
\hline & & & & & & [ha/h] & [h/ha & ] [th] & [hah] [h/ha] [t/h] & [hatho] & [thop] \\
\hline 780 & 126 & 0.44 & 94 & 6.3 & 0.9 & 0.52 & 1.90 & 3.13 & $\begin{array}{llll}0.38 & 2.60 & 2.34\end{array}$ & 0.19 & 1.17 \\
\hline 919 & 136 & 0.45 & 95 & 60 & 1.2 & 0.59 & 1.70 & 3.900 & $\begin{array}{llll}0.39 & 2.60 & 2.54\end{array}$ & 0.20 & 1.27 \\
\hline 952 & 144 & 0.56 & 94 & 7.4 & 1.0 & 0.53 & 1.90 & $3.8 t$ & $0.36 \quad 2.70 \quad 2.70$ & 0.18 & 1.35 \\
\hline 1143 & 140 & 0.51 & 95 & 7.3 & 1.0 & 0.48 & 2.10 & 3.39 & $0.32 \quad 3.10 \quad 2.27$ & 0.16 & 1.14 \\
\hline 1203 & 133 & 0.48 & 94 & 7.6 & 1.0 & 0.45 & 2.20 & 3.43 & $\begin{array}{llll}0.37 & 3.20 & 2.33\end{array}$ & 0.16 & 1.17 \\
\hline 1481 & 126 & 0.49 & 95 & 8.4 & 0.8 & 0.36 & 2.70 & 3.12 & $0.26 \quad 3.80 \quad 2.22$ & 0.13 & 1.11 \\
\hline 1569 & 132 & 0.49 & 9.4 & 8.7 & 0.9 & 0.36 & 2.80 & -3.30 & $0.26 \quad 3.80 \quad 2.30$ & 0.13 & 1.15 \\
\hline 2000 & 115 & 0,48 & 94 & 30.4 & 0.8 & 0.32 & 3.10 & 3.33 & $0.22 \quad 5.60 \quad 2.26$ & $0.1 \%$ & 1.13 \\
\hline 2254 & 82 & 0.35 & 95 & 11.6 & 0.8 & 0.29 & 3.40 & 3.43 & a.s 5.002 .00 & 0.09 & 1.04 \\
\hline 2580 & 64 & 0.24 & 94 & 32.0 & 0.9 & 0.26 & 3.80 & 3.15 & $0.17 \quad 6.0001 .98$ & 000 & 0.90 \\
\hline
\end{tabular}

TABLE 10 - Average values of the parameters assessed and harvesting capacities ( cv. "Arbequina” Agromillora selection) - Thesis B.

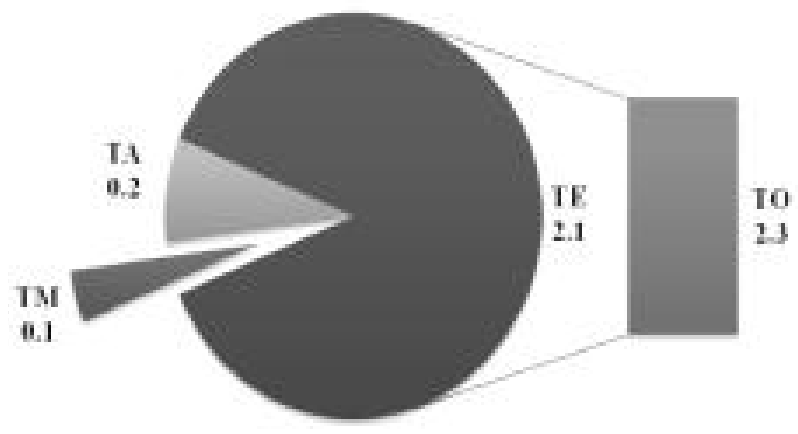

Fig. 6 - Work Times Comparison.

\begin{tabular}{|c|c|c|c|c|c|}
\hline $\mathrm{TE}$ & \multicolumn{3}{|c|}{ TA } & 10 & $\mathrm{TM}$ \\
\hline & $\begin{array}{l}\text { TAV } \\
{[\%]}\end{array}$ & $\begin{array}{l}\text { TAS } \\
{[\%]}\end{array}$ & $\begin{array}{l}\text { TOTAL } \\
\text { [h/ha] }\end{array}$ & [h/ha] & [thla] \\
\hline 2.1 & 35 & 65 & 0.2 & 2.3 & 0.1 \\
\hline
\end{tabular}

TABLE 11 - Times assessed (average values).
Hence the work capacity of the harvester (CO) turned out to be $0.45 \mathrm{ha} / \mathrm{h}$, while the work productivity $(\mathrm{PO})$ was $0.22 \mathrm{ha} / \mathrm{hop}$. Drupe loss was on the order of $6 \%$.

\section{Remarks on the results obtained}

The experiments conducted have shown that, in spite of the many mechanical and agronomic factors likely to have a heavy impact on continuous harvesting systems, super intensive olive orchard cultivation presents clear advantages in terms of abatement of hours of work. Among the main issues emerged it is worthwhile mentioning the challenging identification of the best suited varieties to such cultivation model in view of the requirement of keeping plants vigor under control to allow the passage of harvesters.

Indeed, one of the most pressing needs is guaranteeing the best mutual adaptation between machine and plants in order to maximize harvest efficiency. The analyses carried out within the present study do highlight that Arbequina I-18 seems to be the variety

\begin{tabular}{|c|c|c|c|c|c|c|c|}
\hline \multirow{3}{*}{$\begin{array}{c}\text { Total Wank } \\
\text { Lengeh } \\
\text { [m] }\end{array}$} & \multirow{3}{*}{$\begin{array}{c}\text { Prodinct } \\
\text { Harnesrad } \\
\text { [t] }\end{array}$} & \multirow{3}{*}{$\begin{array}{c}\text { Harvesting } \\
\text { effowency } \\
\text { /\%] }\end{array}$} & \multirow{3}{*}{$\begin{array}{l}\text { Yicid } \\
\text { [that }\end{array}$} & \multirow{3}{*}{$\begin{array}{l}\text { Speed of } \\
\text { adtancermowt } \\
{\left[\mathrm{kw}_{\mathrm{w}} \mathrm{h}\right]}\end{array}$} & \multicolumn{2}{|c|}{$\begin{array}{c}\text { Work } \\
\text { Capacity }\end{array}$} & \multirow{2}{*}{$\begin{array}{c}\text { Work } \\
\text { Productivity } \\
\text { In Terms of To }\end{array}$} \\
\hline & & & & & In Terms of TE & In Terms of To & \\
\hline & & & & & [has] [h/ha] [th] & [ha/h] [h/ha] [th] & [hahop] [thop] \\
\hline $14 J 7$ & 3.6 & 94 & 8.4 & I.6 & $0.48 .2 .1 \quad 4.11$ & $\begin{array}{llll}0.45 & 2.3 & 3.80\end{array}$ & 0.22 \\
\hline
\end{tabular}

TABLE 12 - Average values of the parameters measured and work capacity. 
best suited to super intensive cultivation as the work times assessed for this variety during the tests performed turned out to be the lowest.

The results obtained for Thesis $B$ highlight that for higher densities a better yield corresponds to an increase in the time required to accomplish harvesting operations. In addition, as olive groves age, decreases in yield occur for higher densities which are ascribable to a decreased level of illumination. This phenomenon does occur especially in the presence of favorable growth conditions and of disproportionate relations between the height and the width of the hedge-like row. Therefore the ideal number of plants per hectare remains to be established together with the minimum investment required to obtain the best of productivities.

Another interesting factor is the impact that the length of the individual rows is likely to have on the operation of the harvesters in question. In Andalucía the presence of rows of contained length ( $42 \mathrm{~m}$ on average) has had a negative impact on the harvester work capacity due to the resulting increase in accessory times. Other negative impacts were also observed which were ascribable to the small size of the dirt lanes used to turn the harvester as well as to location of the unloading area far from the area being tested to favor weighing operations of the olives harvested. As a result a significant increase in terms of harvester operation efficiency can be obtained (as confirmed by the higher levels of productivity observed in Cataluña compared to those of Andalucía) by designing the systems in question in a view to predisposing them to an integrated harvesting system, i.e. increasing the length of rows and containing logistic problems (narrow dirt lanes, poor road system, elevated slopes).

The two grape harvesters under study were highly performing as they succeeded in detaching almost all the drupes (more than 90\%), with one only passage, and this independently of both size and location of drupes on the tree crown and of their maturity stage. These same factors have repeatedly been observed to have a negative impact on the work efficiency of harvesting machines relying on tree shakers [Tous 2006]. As to the technical problems observed, with the exception of little drawbacks linked to the need to make stopovers to remove leaves from beaters, no significant problem (in terms of machine reliability) was observed. Quite the contrary, both harvesters turned out to be highly performing in terms of work productivity and quality. It should be emphasized, in fact, that damage to both harvested olives and plants, (wounds, tearings, branch breaks) was neglectable and confined to the most vigorous branches protruding from the row. This kind of drawback could be overcome with an appropriate pruning technique [Loreti 2007]. It should be additionally emphasized that these machines have been remarkably upgraded over time in terms of both design and technology. These improvements have allowed to overcome some constraints of the past in terms of harvest efficiency and machine handling. The cost of these machines however remains high (around 180-200,000 Euros), even if it should be considered that they can work for a total of four months: two for harvesting grapes and two for harvesting olives. A possible solution to the problem of the high price of the harvesters in question could be found by either establishing associations of co-owners or outsourcing harvesting operations. In Spain this problem is usually solved by renting the machines for 120 euro/ha [Loreti 2007].

\section{Conclusions}

The increased interest in state-of-the-art olive growing systems on the part of olive growers all over the world is accounted for by the need to satisfy the demands of a more and more competitive global market. Innovative mechanized harvesting operations represent a real watershed in the process of modernization of world olive growing. The super intensive model, which responds to issues linked to chronic shortage of labor and to the need to contain production costs, is likely to revamp that portion of obsolete and non cost-effective practices which are no longer competitive in the olive growing sector [Giametta 2006a; Giametta 2007b].

The notion of subsistence olive growing, on which traditional olive growing relies, has to come to terms with a the new notion of income olive growing which is meant to contain costs and reach appropriate levels of productivity while safeguarding olive quality [Fontanazza 1996a]. Integrated mechanical harvest allows to exploit at best the ideal time of plant maturity, to avoid olive manipulation at most and to speed up olive transportation to the olive mill.

The performance of the two grape harvesters (Braud and Grégoire) tested has turned out to be highly positive, thus confirming the soundness of the super intensive cultivation model in terms of containing both time and costs by resorting to a crew of only two workers.

Experimental studies aimed to establish several fundamental parameters of super intensive cultivation are presently being conducted to express a final judgment on the model in question also in terms of ideal varieties and planting densities. One such parameters has to do with the economic (in addition to "biologic") duration of the crops and the best form of management of the hedge-like row in the different phases of vegetative development. Plant breeding studies are presently underway to select reduced vigor genotypes specifically adapted to super intensive cultivation [Mallen 2006]. Indeed variety diversity is likely to become an interesting factor in view of the different levels of adaptation of the different cultivars to specific environmental conditions as well as in view of different degrees of susceptibility of the same to pathogens attacks, not to mention the possibility of availing of a diversified produce over time also in terms of quality, a factor likely to make a difference to respond to the needs of a global market [De la Rosa 2006a; De la Rosa 2007b].

The possibility to introduce this system in Italy remains to be assessed, especially in terms of the choice 
of the cultivar to be used as well as in terms of the logistic problems linked to the orography of Italian territory and, last but not least, in terms of adaptation of the entire chain of production (oil mills, packhouses) to the super intensive model which is characterized by a workload concentrated in only 30-40 days and no longer spread over the traditional 3 to 4 -month period.

\section{Acknowledgements}

The authors extend their thanks to the University of Cordoba (ES), especially Prof. Luis Rallo Romero, to CIFA - Alameda del Obispo (Junta de Andalucía), to Todolivo S.L., to the Institut de Recerca y Tecnologia Agroalimentaries (IRTA - Centre Mas Bové de Cataluña) and notably Joan Tous, for his invaluable contribution to the present study.

\section{References}

Arrivo A., Bellomo F., D’Antonio P., Raccolta meccanica nell'oliveto superintensivo. L'Informatore Agrario, 2006, (1), 68-71.

Barranco D., Fernandez-Escobar R., Rallo L., El Cultivo del Olivo, $5^{\text {a }}$ Ed., Mundi Prensa, 2004, Madrid.

Bellomo F, D'Antonio P., Limiti di convenienza dell'utilizzazione di una vendemmiatrice per la raccolta delle olive in impianto superintensivo. Convegno Nazionale AIIA su " Tecnologie innovative nelle filiere: orticola, vitivinicola e olivicola-olearia", 2007, Pisa e Volterra 57 settembre, 37-40.

Bolli P., Scotton M., Lineamenti di tecnica della meccanizzazione agricola, $1^{\text {a }}$ ed., Edagricole, 1987, Bologna.

Cini F., Giametta G., Meccanizzazione dell'olivicoltura negli impianti tradizionali e intensivi. Convegno Nazionale AIIA su "Tecnologie innovative nelle filiere: orticola, vitivinicola e olivicola-olearia”, 2007, Pisa e Volterra 5-7 settembre, 3-5.

Corradi C., Guida alla scelta della vendemmiatrice. Terra e Vita, 2005, 45, 75-82.

De La Rosa R., Leon L., Guerrero N., Barranco D., Rallo L., Resultados preliminares de un ensayo de densidades de plantacion en olivar en seto. Fruticultura Profesional, $2006^{\circ}, \mathrm{IV}(160), 43-46$.

De La Rosa R., Leon L., Guerrero N., Barranco D., Rallo L., Tous J., Romero A., Hermoso J.F., Ensayos de variedades de olivo en plantacion de alta densidad. Comparacion de resultados entre Andalucía y Cataluña. Fruticultura Profesional, 2006b, IV(160), 21-26.

Fontanazza G., Tecniche intensive di coltivazione dell'olivo. L'Informatore Agrario, 1996a, (44), 39-43

Fontanazza G., Bartolozzi F., Vergati G., Olivo Fs-17. Rivista di Frutticoltura e Ortofloricoltura, 1998b, 60(7/8), 61.

Giametta G., Relazione generale. Seminario Internazionale su: "Innovazione tecnologica in olivicoltura tra esigenze di qualità e di tutela ambientale", 2006a, Cittanova (RC) 11 settembre, 9-13.

Giametta G., Spagna, raccolta a scavallo degli oliveti superintensivi. Olivo e Olio, 2007b, (2), 23-26.

Godini A., Camposeo S., Scavo V., Gli aspetti agronomici dell'olivicoltura superintensiva. L'Informatore Agrario, 2006, (1), 65-67.

Iannotta N., Perri E., L'esperienza della Spagna nell'olivicoltura superintensiva. L'Informatore Agrario, 2006, (1), 59-63.
Loreti F., Alta densità: rivoluzione globale nelle tecniche di coltivazione dell'olivo, Rivista di Frutticoltura e Ortofloricoltura, 2007, (7/8), 56-70.

Mallen N., Romero A., Tous J., Situación actual del uso de patrones en olivo. Fruticultura Profesional, 2006, IV(160), 7-11.

Rallo L., De la Rosa R., León L., Guerrero N., Barranco D., L'olivicoltura intensiva in Spagna. Seminario internazionale su: "Innovazione tecnologica in olivicoltura tra esigenze di qualità e di tutela ambientale", 2006, Cittanova (RC) 11 settembre, 21-25.

Scaramuzzi F., Gradienti di vegetazione e nuove forme di allevamento dell'olivo. Italia Agricola, 1962a, 7.

Scaramuzzi F., Orientamenti per l'impianto di nuovi oliveti, Italia Agricola, 1964b, 11.

Scaramuzzi F., Innovazione della olivicoltura tra esigenze tecnico-economiche globali e pretesa conservazione del paesaggio agricolo. Seminario Internazionale su: "Innovazione tecnologica in olivicoltura, tra esigenze di qualità e di tutela ambientale", 2006c, Cittanova (RC) 11 settembre, 15-20.

Tous J., Romero A., Hermoso J.F., High density planting systems, mechanization and crop management in olive. Second International Seminar: Olivebioteq, 2006, Marsala - Mazara del Vallo 5-10 Novembre, 423-430.

\section{SUMMARY}

Today also those countries boasting a century-old olive growing tradition have to look at the latest, most dynamic, non labour-intensive olive growing systems to abate production (notably, harvesting operations) costs and remain competitive in a globalized market. This is why over the last few years super intensive olive orchard cultivation has been attracting a lot of interest on the part of olive growers all over the world as it accounts for an innovative model whereby olive groves are tailored to the special needs of grape harvesters.

This paper reports the first results of experimental mechanical harvesting tests in a super-intensive olive cultivation. The study is intended to explore both productivity and work capacity of two of the most commonly used grape harvesters, Grégoire G120SW and New Holland Braud VX680, in a view to assessing their harvesting performance by a series of tests conducted in Spain. On the basis of the tests it was possible to verify that the machines are able to detach the almost all the drupes (more than 90\%), with one only passage, and this independently of both size and location of drupes on the tree crown and of their maturity stage.

Using these machines, two people can often carry out the whole harvest process: an operator driving the harvester and another person transferring the fruit from the harvester in the field to the olive oil mill for processing. With this system, the work speed is usually, in the best working conditions, about $1.7 \mathrm{~km} /$ hour and the average harvesting time is about 2.5-3 hours/ha.

For the time being it is however impossible to draw definitive conclusions in terms of performance of the above cultivation systems and harvesting machines. Additional key observational studies are needed in the years to come to assess the efficiency of the entire model.

Keywords: Super intensive Olive Growing, Grape Harvesters, Productivity. 